\title{
POLA KONSUMSI ANAK UMUR 6 BULAN - 12 TAHUN DI INDONESIA
}

\author{
Edith Sumedi ${ }^{1,4}$, Yekti Widodo 2.4, Sandjaja ${ }^{3,4}$ \\ 1 Jurusan Gizi, Politeknik Kesehatan Kemenkes Jakarta II \\ 2Pusat Teknologi Intervensi Kesehatan Masyarakat \\ 3Pusat Teknologi Terapan Kesehatan dan Epidemiologi Klinik \\ 4Persatuan Ahli Gizi Indonesia (PERSAGI) \\ edith.sumedi@yahoo.com
}

\begin{abstract}
ABSTRAK
Pertumbuhan dan perkembangan anak berada dalam pengaruh dan pengasuhan orang tuanya, dan gizi merupakan salah satu faktor penting yang mempengaruhi pertumbuhan, kesehatan dan perkembangan anak. Salah satu penyebab tingginya prevalensi kurang gizi di Indonesia adalah kurang baiknya pola asuh anak, pola konsumsi anak, dan ketersediaan makan keluarga. South East Asian Nutrition Surveys (SEANUTS) di Indonesia dilaksanakan di 48 kabupaten mencakup 7211 anak 6 bulan - 12 tahun. Pola konsumsi anak menggunakan Food Frequency Questionnaires (FFQ) melalui wawancara pola kebiasaan makan satu bulan terakhir meliputi frekuensi jenis makanan sehari, seminggu atau sebulan, cara pengolahan dan cara penyajian, merek (jika ada) berdasarkan kelompok sumber zat gizi yaitu makanan pokok, protein hewani dan nabati, sayur, buah, jajanan, minuman dan susu. Analisis data deskriptif yang menurut daerah dan dibagi menjadi 5 kelompok umur 6-11 bulan, 1-2 tahun, 3-5 tahun, 6-8 tahun dan 9-12 tahun. Hasil penelitian ini menunjukkan bahwa pola konsumsi anak umur 6-11 bulan hampir sama di kota maupun di desa. Variasi bahan makanan lebih banyak dijumpai pada kelompok umur yang lebih tua dan terdapat perbedaan pola makan antara perkotaan dan perdesaan. Konsumsi makanan pokok tidak berbeda antara perkotaan dan perdesaan. Frekuensi makan sayur dan buah masih rendah di kedua daerah. Anak di perkotaan lebih sering mengonsumsi daging unggas, daging sapi, telur, tahu, bayam, wortel, susu/produk susu, minuman gelas/serbuk, sedangkan di perdesaan lebih sering mengonsumsi ikan laut, tempe, kangkung, jajanan 'chiki' dan sejenisnya. Masih diperlukan peningkatan perilaku hidup sehat dengan memperbaiki pola makan gizi seimbang.
\end{abstract}

Kata kunci: pola konsumsi, frekuensi makan, anak Indonesia

ABSTRACT

\section{FOOD PATTERN OF INDONESIAN CHILDREN 6 MONTH - 12 YEAR OF AGE}

Child growth and development under the nurture and care of their parents, and nutrition as a factor in growth, health and development of children. Many factors associated with high prevalence of malnutrition are caring pattern of children, inadequate food consumptions and food patterns, and household food availability. The South East Asian Nutrition Survey (SEANUTS) in Indonesia conducted in 48 districts collected data on food consumption pattern of 7,211 children 6 month - 12 year of age. Food consumption pattern was collected by using food frequency questionnaires (FFQ) to describe food habits based on daily, weekly, and monthly frequency of food items by interviewing mothers. Food items collected from all food groups such as foods source of carbohydrates, animal and plant proteins, vitamin and mineral source from vegetables and fruits, milk and milk products, snacks, and beverages. Descriptive analysis was used to describe food consumption pattern by residence and 5 age groups 6-11 month, 1-2, 3-5, 6-8, and 9-12 year of age. Result showed similarity of food consumption pattern in urban and rural area in youngest age group. The variety of food items consumed by older age groups is more than those in younger ones, and as also found in urban than rural areas. There was similarity in staple food and less consumption of vegetable and fruit in urban than rural areas across age groups. The frequency of white meat, red meat, egg, tofu, spinach, carrot, dairy products, and beverages was higher in urban than rural areas. The frequency of salty fish, tempeh, swamp cabbage, "chiki' snack was higher in rural than urban areas. Healthy living and balance diet (Gizi Seimbang) promotion of all food groups particularly vegetable and fruit should be revitalized.

Keywords: food pattern, food frequency, Indonesian children 


\section{PENDAHULUAN}

$\mathrm{M}$ asalah gizi di Indonesia masih cukup tinggi. Hal ini tampak dari prevalensi gizi kurang dan gizi buruk 17,9 persen, kependekan (pendek dan sangat pendek) 35,6 persen, kekurusan (kurus dan sangat kurus) sebesar 13,3 persen, di lain pihak prevalensi kegemukan sudah cukup tinggi 14 persen. ${ }^{1}$ Menurut hasil Riskesdas 2010, prevalensi anak pendek umur 6-12 tahun 35,6 persen, sedangkan prevalensi kurus anak umur 6-12 tahun 12,2 persen dan kegemukan 9,2 persen. ${ }^{1}$

Pola makan merupakan perilaku penting yang dapat mempengaruhi keadaan gizi. Hal ini disebabkan kuantitas dan kualitas makanan dan minuman yang dikonsumsi akan mempengaruhi tingkat kesehatan individu dan masyarakat. Konsumsi pangan masyarakat masih belum sesuai dengan anjuran makan yang dicanangkan oleh pemerintah melalui Pesan Gizi Seimbang. ${ }^{2}$

Latar belakang pelaksanaan penelitian SEANUTS adalah bahwa wilayah Asia Tenggara mengalami transisi penduduk dan epidemiologi karena pertumbuhan ekonomi yang tinggi. Seiring dengan hal tersebut, terjadi pula perubahan pola makan masyarakat, sosial, ekonomi, perilaku pada semua kelompok umur termasuk anak. Selain itu terjadi pula beban ganda masalah gizi dalam waktu yang sama.

Di lain pihak tidak semua negara kawasan ASEAN punya informasi status gizi secara nasional dan komprehensif. Oleh karena itu diperlukan data berbasis bukti guna mengetahui lebih dalam status gizi anak di ASEAN, faktor risiko, dan dampaknya.

Studi SEANUTS Indonesia dilakukan tahun 2011, meliputi 48 Kabupaten/kota di Indonesia dan dipilih secara acak, diperoleh sampel anak usia 0,5-12,9 tahun sebanyak 7.211 anak. Dalam penelitian SEANUTS ini dilakukan pengambilan data tentang pola makan berdasarkan asupan 24 jam dan frekuensi konsumsi bahan makanan.

\section{METODE PENELITIAN}

Data utama dalam tulisan ini adalah data food frequency questionnaires (FFQ) yang merekam kebiasaan makan anak selama sebulan terakhir. Data dikumpulkan dengan cara wawancara. Frekuensi setiap jenis bahan makanan dikumpulkan berdasarkan informasi dari ibu/pengasuh dan sampel khususnya sampel yang biasa mengonsumsi makanan di luar rumah. Frekuensi konsumsi makanan dikelompokkan berdasarkan frekuensi konsumsi dalam sehari, dalam seminggu, dan dalam sebulan terakhir. Data frekuensi konsumsi dihitung dengan cara mentransformasikan data frekuensi konsumsi setiap jenis bahan makanan ke dalam satuan frekuensi konsumsi yang sama, yaitu konsumsi dalam sebulan.

Cara transformasi data frekuensi konsumsi makanan adalah frekuensi dalam sehari ditransformasi ke dalam frekuensi sebulan dengan cara dikalikan 30; frekuensi dalam seminggu ditransformasi ke dalam frekuensi sebulan dengan cara dikalikan 7,25 , dan frekuensi dalam sebulan ditransformasi ke dalam frekuensi sebulan dengan cara dikalikan 1. Hasil perkalian tersebut adalah frekuensi konsumsi makanan dalam sebulan, sehingga penyajian datanya dikategorikan menjadi 4 kategori, yaitu: (1) $\geq 90$ kali sebulan (bisa dinyatakan $\geq 3$ kali sehari); (2) 30-89 kali sebulan (bisa dinyatakan 1-2 kali sehari); (3) $<30$ kali sebulan (bisa dinyatakan $<1$ kali sehari); dan (4) tidak pernah mengonsumsi (dalam sebulan terakhir tidak penah mengonsumsi jenis makanan tersebut).

Analisis dan penyajian data frekuensi konsumsi makanan dalam sebulan terakhir dikelompokkan menurut 5 kelompok umur, yaitu: (1) umur 6-11 bulan, (2) umur 1-2 tahun, (3) umur 3-5 tahun, (4) umur 6-8 tahun, dan (5) umur 9-12 tahun. Bahan makanan dikelompokkan menjadi 22 kelompok berbahan dasar sama yang mencakup kelompok bahan makanan pokok, lauk (sumber protein hewani dan nabati), sayuran, buah, susu dan produk susu, makanan jajanan biskuit, chiki, permen, dan minuman, yang paling sering dikonsumsi anak. Dua puluh dua jenis bahan makanan tersebut adalah: beras/nasi, mie/bihun, ubi, singkong, daging unggas (ayam, bebek, burung) daging merah (sapi, kambing, babi), ikan laut, ikan tawar, telur (telur ayam, telur bebek, telur puyuh) tahu, tempe, jeruk, pepaya, pisang, bayam, kangkung, wortel, susu dan produk susu, jajanan biskuit, jajanan chiki, jajanan permen, jajanan minuman gelas dan serbuk. Bahan makanan dengan frekuensi yang rendah tidak disajikan. Data FFQ dianalisa menggunakan program software SPSS versi 13. 


\section{HASIL}

\section{Jenis bahan makanan yang dikonsumsi anak Indonesia 6 bulan - 12 tahun}

Jenis makanan yang dikonsumsi anak umur 6 bulan - 12 tahun di Indonesia disajikan pada Tabel 1. Tidak semua jenis makanan yang dikonsumsi dianalisis, namun hanya 22 jenis bahan makanan atau kelompok bahan makanan dengan frekuensi konsumsi tinggi yang disajikan dalam tulisan ini. Kelompok sumber makanan pokok adalah nasi/beras, mie/bihun, ubi dan singkong. Bahan makanan sumber protein hewani adalah daging unggas/ayam, daging merah (sapi, kambing, babi), ikan laut, ikan tawar dan telur, sedangkan bahan makanan sumber protein nabati yang paling sering dikonsumsi adalah tahu dan tempe.

Tabel 1

Jenis Bahan Makanan, Minuman, Jajanan, dan Susu yang Dikonsumsi Anak 6 bulan - 12 Tahun menurut Kelompok Sumber Sumber Pangan

\begin{tabular}{|c|c|}
\hline $\begin{array}{l}\text { Kelompok } \\
\text { Sumber Pangan }\end{array}$ & Nama bahan makanan \\
\hline Makanan pokok & $\begin{array}{l}\text { Beras, Beras merah, Ketan putih, Ketan hitam, Sagu, Ubi, Singkong, Tepung } \\
\text { beras, Terigu, Kentang, Jagung, Mie, Bihun, Talas, Berbagai merk bubur bayi }\end{array}$ \\
\hline Hewani & $\begin{array}{l}\text { Ayam, Rusa, Kambing, Lembu, Kuskus, Kuda, Kasuari, Kerbau, Bebek, Domba, } \\
\text { Mentok, Kambing, Sapi, Keong, Kerang, Ati ayam, Ati Sapi, Rempela Ayam, } \\
\text { Anjing, Babi, Bakso, lkan laut, Ikan tawar, Cumi, Kepiting, Usus ayam, Tutut (siput } \\
\text { sawah), Udang, Keju }\end{array}$ \\
\hline Nabati & $\begin{array}{l}\text { Tempe, Tahu, Kacang tanah, Kacang Polong, Kacang merah, Kacang sukro, } \\
\text { Kacang Hijau, Kacang kedelai, Kacang koro, Oncom }\end{array}$ \\
\hline Sayuran & $\begin{array}{l}\text { Bayam, Bayam merah, Buncis, Kacang panjang, Daun papaya, Daun kacang } \\
\text { panjang, Daun kelor, Daun Kenikir, Daun katuk, Daun lobak dan Lobak, Daun } \\
\text { melinjo, Daun pakis, Daun singkong, Daun saga, Daun ubi, Daun tales, Daun } \\
\text { tangkil, Daun bawang, Daun marungga, Daun turi, Nangka muda, Brokoli, Buncis, } \\
\text { Bunga kol, Kol, Bunga papaya, Papaya muda, Jamur, Jamur kuping, Jantung, } \\
\text { Taoge, Kangkung, Kacang kapri, Kecipir, Leunca, Selada, Kol, Ketimun }\end{array}$ \\
\hline Buah & $\begin{array}{l}\text { Apel, Anggur merah, Anggur hijau, Anggur hitam, Strawbery, Belimbing, } \\
\text { Bengkoang, Nangka, Pepaya, Cherry/kersen, Ceremai, Delima, Dukuh, Durian, } \\
\text { Blewah, Melon, Pisang, Jambu air, Jambu biji merah, Jambu biji putih, Jeruk, } \\
\text { Sirsak, Buah naga, Kedondong, Kelengkeng, Markisa, Matoa, Mangga, } \\
\text { Semangka, Nanas }\end{array}$ \\
\hline Susu/produk susu & $\begin{array}{l}\text { Berbagai merk susu bubuk, Berbagai merk susu cair, Susu fermentasi, Susu } \\
\text { segar, Susu kental manis, Susu kotak, Susu bantal, Ice cream, Susu cair dalam } \\
\text { kemasan, Keju, dan Yogurt }\end{array}$ \\
\hline Jajanan biskuit & $\begin{array}{l}\text { Berbagai jenis dan merek biskuit: Astor, Regal, Coklat, Farley, Bagin, Krakers, } \\
\text { Malkist, Marie, Milna, Piramid, Roma, Selai }\end{array}$ \\
\hline Jajanan chiki & $\begin{array}{l}\text { Berbagai chiki dan sejenisnya: Taro, Chitos, Tictac, Zacky, Upin-Ipin, Aries, Ben } \\
\text { 10, Chotato, Chitatos, Chuba, Komo, Leo, dan lainnya, serta Chiki tanpa merek }\end{array}$ \\
\hline Jajanan permen & $\begin{array}{l}\text { Berbagai jenis permen: Fox, Kopiko, Kiss, Relaxa, Permen karet, Alpenleibe, } \\
\text { Blaster, Bigbabol, Jagoan, Neon, Milkita, Lolipop, dan lainnya. }\end{array}$ \\
\hline Jajanan minuman & $\begin{array}{l}\text { Berbagai jajanan mimunan gelas dan jajanan minuman serbuk. Jajanan minuman } \\
\text { gelas adalah: Ale-ale, Frutang, Fruitamin, Freshtea, Fruitea, Cocodrink, Greentea, } \\
\text { Jellydrink, Mountea, Natadecoco, Teh gelas. Jajanan minuman serbuk adalah: } \\
\text { Nutrisari, Jasjus, Pop Ice, Top Ice, Teh Sisri, Marimas }\end{array}$ \\
\hline
\end{tabular}


Buah-buahan yang paling sering dikonsumsi adalah jeruk, pepaya dan pisang. Konsumsi tertinggi untuk sayuran adalah bayam, kangkung, dan wortel. Selain itu juga disajikan konsumsi susu/produk susu, makanan jajanan berupa berbagai jenis biskuit, chiki, permen, dan jajanan minuman berupa minuman kemasan gelas dan minuman serbuk.

\section{Frekuensi konsumsi bahan makanan yang terbanyak dikonsumsi oleh anak Indonesia 6 bulan - 12 tahun}

Berdasarkan Tabel 2 pada kelompok umur 6-11 bulan, 42,3 persen di perkotaan mengonsumsi beras setiap hari, sedangkan di perdesaan 53,3 persen. Sumber karbohidrat lainnya seperti mie, singkong dan ubi lebih dari 90 persen tidak pernah mengonsumsi (sangat jarang dikonsumsi). Bahan makanan sumber protein hewani yang paling sering dikonsumsi di perkotaan dan di perdesaan adalah telur.
Proporsi anak umur 6-11 bulan di perkotaan relatif lebih sering mengonsumsi makanan sumber protein dari pada anak di perdesaan. Frekuensi protein nabati yaitu tahu dan tempe di perkotaan relatif lebih rendah daripada di perdesaan. Proporsi anak yang mengonsumsi tahu dan tempe setiap hari di perkotaan sangat rendah yaitu masing-masing 1,8 persen dan 1,9 persen sedangkan di pedesaan masing-masing 4,1 persen dan 3,5 persen.

Jenis buah-buahan yang paling sering dikonsumsi pada kelompok umur 6-11 bulan adalah pisang yang dikonsumsi setiap hari, di perkotaan 0,6 persen sedangkan di perdesaan 2,9 persen. Sayuran yang paling sering dikonsumsi adalah bayam dan wortel, di perkotaan masing-masing 4,3 persen dan 5,6 persen sedangkan di perdesaan masing-masing 4,7 persen dan 6,5 persen. Susu dan produk susu adalah jenis makanan yang paling sering dikonsumsi oleh kelompok umur 6-11 bulan.

Tabel 2

Pola Konsumsi Makanan Anak Kelompok Umur 6-11 Bulan menurut Perkotaan dan Perdesaan

\begin{tabular}{|c|c|c|c|c|c|c|c|c|c|}
\hline \multirow{3}{*}{$\begin{array}{l}\text { Nama } \\
\text { Bahan Makanan }\end{array}$} & \multicolumn{8}{|c|}{ Frekuensi Konsumsi Anak dalam Sebulan } & \multirow{3}{*}{$\begin{array}{c}\text { Nilai } \\
p\end{array}$} \\
\hline & \multicolumn{4}{|c|}{ Perkotaan } & \multicolumn{4}{|c|}{ Perdesaan } & \\
\hline & $\begin{array}{l}\geq 90 \\
\text { kali }\end{array}$ & $\begin{array}{c}30-89 \\
\text { kali }\end{array}$ & $\begin{array}{l}<30 \\
\text { kali }\end{array}$ & $\begin{array}{l}\text { Tidak } \\
\text { pernah }\end{array}$ & $\begin{array}{l}\geq 90 \\
\text { kali }\end{array}$ & $\begin{array}{c}30-89 \\
\text { kali }\end{array}$ & $\begin{array}{l}<30 \\
\text { kali }\end{array}$ & $\begin{array}{c}\text { Tidak } \\
\text { pernah }\end{array}$ & \\
\hline Nasi/beras & 5,5 & 36,8 & 12,3 & 45,4 & 3,6 & 49,7 & 5,9 & 40,8 & 0,046 \\
\hline Mie/bihun & 0 & 0 & 6,8 & 93,2 & 0 & 0 & 8,8 & 91,2 & 0,797 \\
\hline Ubi jalar & 0 & 0 & 9,9 & 90,1 & 0 & 0 & 4,1 & 95,9 & 0,038 \\
\hline Singkong & 0 & 0 & 4,3 & 95,7 & 0 & 0 & 4,1 & 95,9 & 0,917 \\
\hline Daging unggas & 0 & 0 & 25,5 & 74,5 & 0 & 0 & 17,6 & 82,4 & 0,392 \\
\hline Daging sapi/sejenis & 0 & 2,5 & 21,0 & 76,5 & 0 & 0,6 & 15,8 & 83,6 & 0,156 \\
\hline Ikan laut & 0 & 0,6 & 16,8 & 82,6 & 0 & 1,8 & 12,9 & 85,3 & 0,618 \\
\hline Ikan tawar & 0 & 0,6 & 21,1 & 78,3 & 0 & 0 & 13,0 & 87,0 & 0,082 \\
\hline Telur ayam/bebek & 1,2 & 3,1 & 30,4 & 65,2 & 0 & 0,6 & 32,9 & 66,5 & 0,159 \\
\hline Tahu & 0,6 & 1,2 & 39,5 & 58,6 & 0 & 4,1 & 32,9 & 62,9 & 0,184 \\
\hline Tempe & 0 & 1,9 & 27,3 & 70,8 & 0 & 3,5 & 28,7 & 67,8 & 0,611 \\
\hline Jeruk & 0 & 0 & 35,4 & 64,6 & 0 & 0 & 33,5 & 66,5 & 0,938 \\
\hline Pepaya & 0 & 0 & 23,6 & 76,4 & 0 & 0 & 15,3 & 84,7 & 0,056 \\
\hline Pisang & 0 & 0,6 & 49,1 & 50,3 & 0 & 2,9 & 34,5 & 62,6 & 0,012 \\
\hline Bayam & 0,6 & 3,7 & 40,7 & 54,9 & 0,6 & 4,1 & 39,8 & 55,6 & 0,996 \\
\hline Kangkung & 0 & 0 & 4,3 & 95,7 & 0 & 0 & 7,0 & 93,0 & 0,295 \\
\hline Wortel & 0 & 5,6 & 46,6 & 47,8 & 0,6 & 5,9 & 32,9 & 60,6 & 0,062 \\
\hline Susu/produk susu & 29,8 & 18,0 & 6,8 & 45,3 & 12,3 & 12,9 & 4,7 & 70,2 & 0,000 \\
\hline Jajanan biskuit & 6,2 & 8,1 & 56,5 & 29,2 & 5,9 & 7,1 & 54,1 & 32,9 & 0,899 \\
\hline Jajanan chiki & 0 & 1,2 & 8,1 & 90,7 & 0 & 0,6 & 7,6 & 91,8 & 0,936 \\
\hline Jajanan permen & 0 & 0 & 4,3 & 95,7 & 0 & 0 & 1,2 & 98,8 & 0,208 \\
\hline Jajanan minuman & 0 & 0,6 & 1,9 & 97,5 & 0 & 0 & 1,2 & 98,8 & 0,518 \\
\hline
\end{tabular}


Proporsi anak kelompok umur 6-11 bulan yang mengonsumsi susu/produk susu setiap hari di perkotaan adalah 47,8 persen sedangkan di perdesaan 25,2 persen, dan 70,2 persen anak di perdesaan tidak pernah mengonsumsi susu dan produk susu. Frekuensi konsumsi susu/produk susu antara anak di perkotaan dan di perdesaan lebih tinggi di perkotaan dan menunjukkan perbedaan yang nyata. Jenis makanan yang paling sering dikonsumsi setiap hari (> 30 kali sebulan) oleh anak kelompok umur 6-11 bulan adalah nasi/beras, susu, biskuit, dan telur.

Jenis makanan jajanan yang paling sering dikonsumsi anak kelompok umur 6-11 bulan di perkotaan dan di perdesaan adalah biskuit. Proporsi anak yang mengonsumsi biskuit tiap hari di perkotaan adalah 14,3 persen dan di perdesaan 13,0 persen. Pada kelompok umur tersebut yang tidak pernah mengonsumsi biskuit dalam sebulan terakhir di perkotaan adalah 29,2 persen dan di perdesaan 32,9 persen. Frekuensi konsumsi biskuit antara anak di perdesaan dan di perkotaan tidak berbeda. Jenis makanan jajanan yang lain sangat jarang dikonsumsi. Pada kelompok umur 6-11 bulan, jenis makanan dengan frekuensi konsumsi yang berbeda nyata antara di perkotaan dan di perdesaan adalah nasi/beras, ubi, pisang, dan susu/produk susu. Frekuensi konsumsi ubi, pisang, dan susu/produk susu lebih tinggi di perkotaan daripada di perdesaan, sedangkan konsumsi nasi/beras lebih tinggi di perdesaan. Pola konsumsi 22 jenis makanan dalam sebulan terakhir pada anak kelompok umur 1-2 tahun disajikan pada Tabel 3.

Tabel 3 menunjukkan pola konsumsi anak umur 1-2 tahun. Nasi/beras merupakan jenis makanan yang paling sering dikonsumsi oleh anak kelompok umur 1-2 tahun, dan jenis bahan makanan yang dikonsumsi lebih bayak dan lebih bervariasi, baik di perkotaan maupun di perdesaan.

Tabel 3

Pola Konsumsi Makanan Anak Kelompok Umur 1-2 Tahun menurut Perkotaan dan Perdesaan

\begin{tabular}{|c|c|c|c|c|c|c|c|c|c|}
\hline \multirow{3}{*}{$\begin{array}{l}\text { Nama } \\
\text { Bahan Makanan }\end{array}$} & \multicolumn{8}{|c|}{ Frekuensi Konsumsi Anak dalam Sebulan } & \multirow{3}{*}{$\begin{array}{c}\text { Nilai } \\
p\end{array}$} \\
\hline & \multicolumn{4}{|c|}{ Perkotaan } & \multicolumn{4}{|c|}{ Perdesaan } & \\
\hline & $\begin{array}{l}\geq 90 \\
\text { kali }\end{array}$ & $\begin{array}{c}30-89 \\
\text { kali }\end{array}$ & $\begin{array}{l}<30 \\
\text { kali }\end{array}$ & $\begin{array}{c}\text { Tidak } \\
\text { pernah }\end{array}$ & $\begin{array}{l}\geq 90 \\
\text { kali }\end{array}$ & $\begin{array}{c}30-89 \\
\text { kali }\end{array}$ & $\begin{array}{l}<30 \\
\text { kali }\end{array}$ & $\begin{array}{c}\text { Tidak } \\
\text { pernah }\end{array}$ & \\
\hline Nasi/beras & 27,2 & 61,9 & 7,7 & 3,3 & 25,7 & 63,0 & 7,9 & 3,3 & 0,940 \\
\hline Mie/bihun & 0 & 0,1 & 66,5 & 33,4 & 0,1 & 2,0 & 72,9 & 25,0 & 0,000 \\
\hline Ubi jalar & 0 & 0 & 23,0 & 77,0 & 0 & 0,4 & 22,1 & 77,5 & 0,227 \\
\hline Singkong & 0 & 0 & 21,5 & 78,5 & 0 & 0 & 23,7 & 76,3 & 0,611 \\
\hline Daging unggas & 0 & 6,1 & 68,1 & 25,8 & 0,3 & 2,9 & 63,8 & 33,0 & 0,001 \\
\hline Daging sapi/sejenis & 0 & 3,4 & 63,9 & 32,7 & 0,1 & 2,2 & 51,0 & 46,6 & 0,000 \\
\hline Ikan laut & 0,3 & 6,1 & 42,7 & 50,9 & 0,6 & 5,4 & 48,2 & 45,8 & 0,178 \\
\hline Ikan tawar & 0 & 0,1 & 43,1 & 56,7 & 0 & 2,2 & 38,3 & 59,4 & 0,002 \\
\hline Telur ayam/bebek & 0,1 & 5,6 & 75,7 & 18,5 & 0,3 & 5,7 & 73,3 & 20,7 & 0,706 \\
\hline Tahu & 0,1 & 5,0 & 74,8 & 20 & 0,6 & 4,1 & 71,8 & 23,6 & 0,181 \\
\hline Tempe & 0 & 5,5 & 76,9 & 17,6 & 0,1 & 4,9 & 75,8 & 19,1 & 0,647 \\
\hline Jeruk & 0 & 0,1 & 56,4 & 43,4 & 0 & 0,4 & 52,1 & 47,5 & 0,186 \\
\hline Pepaya & 0 & 0,1 & 41,8 & 58,1 & 0 & 0 & 23,2 & 76,8 & 0,000 \\
\hline Pisang & 0 & 1,9 & 55,3 & 42,8 & 0,1 & 0,4 & 48,5 & 50,9 & 0,001 \\
\hline Bayam & 0 & 0,9 & 66,4 & 32,7 & 0 & 2,6 & 62,5 & 34,9 & 0,026 \\
\hline Kangkung & 0 & 0,3 & 23,1 & 76,6 & 0 & 0,7 & 33,4 & 65,9 & 0,000 \\
\hline Wortel & 0 & 3,7 & 71,9 & 24,4 & 0 & 1,4 & 48,6 & 50,0 & 0,000 \\
\hline Susu/produk susu & 37,6 & 30,4 & 14,2 & 17,8 & 15,1 & 25,4 & 20,9 & 38,5 & 0,000 \\
\hline Jajanan biskuit & 2,7 & 13,6 & 62,6 & 21,2 & 2,7 & 13,6 & 62,6 & 21,2 & 0,938 \\
\hline Jajanan chiki & 0,9 & 3,7 & 37,6 & 57,8 & 3,4 & 3,9 & 38,1 & 54,6 & 0,015 \\
\hline Jajanan permen & 1,5 & 3,6 & 45,7 & 49,3 & 3,9 & 3,6 & 49,3 & 43,2 & 0,011 \\
\hline Jajanan minuman & 1,8 & 1,2 & 20,1 & 76,9 & 1,0 & 4,1 & 22,1 & 72,9 & 0,003 \\
\hline
\end{tabular}


Proporsi anak kelompok umur 1-2 tahun yang mengonsumsi beras setiap hari di perkotaan adalah 89,1 persen dan di perdesaan 88,7 persen. Pada kelompok umur 1-2 tahun baik di perkotaan maupun di perdesaan pada sudah mulai mengonsumsi mie setiap hari, meskipun persentasenya rendah 0,1 persen dan 2,1 persen. Konsumsi mie/bihun di perdesaan lebih sering daripada di perkotaan $(p<0,05)$.

Konsumsi makanan sumber protein hewani yang terbanyak adalah telur. Di perkotaan 81,5 persen dan di perdesaan 79,3 persen anak umur 1-2 tahun mengonsumsi telur minimal sehari sekali. Pola konsumsi telur di perkotaan dan di perdesaan tidak berbeda, sedangkan pola konsumsi daging unggas dan daging sapi/kambing/babi di perkotaan lebih sering daripada di perdesaan $(p<0,05)$. Konsumsi makanan sumber protein nabati yaitu tahu dan tempe tidak berbeda antara di perkotaan dan perdesaan.
Konsumsi buah pepaya dan pisang berbeda nyata antara anak-anak di perkotaan dan di perdesaan $(p<0,05)$. Anak umur $1-2$ tahun di perkotaan lebih sering mengonsumsi pepaya dan pisang daripada anak di perdesaan. Konsumsi sayur bayam dan wortel lebih sering dikonsumsi anak di perkotaan daripada di perdesaan, sedangkan kangkung lebih sering dikonsumsi anak di perdesaan daripada perkotaan. Pola konsumsi sayur bayam, kangkung, dan wortel di perkotaan dan di perdesaan menunjukkan perbedaan nyata $(p<0,05)$.

Pada anak umur 1-2 tahun di perkotaan lebih sering mengonsumsi susu/produk susu daripada di perdesaan. Proporsi anak di perkotaan yang mengonsumsi susu/poduk susu minimal satu kali seminggu adalah 82,2 persen sedangkan di perdesaan 61,5 persen. Sebaliknya untuk makanan jajanan chiki, permen, dan minuman lebih sering dikonsumsi anak-anak di perdesaan daripada di perkotaan.

Tabel 4

Pola Konsumsi Makanan Anak Kelompok Umur 3-5 Tahun menurut Perkotaan dan Perdesaan

\begin{tabular}{|c|c|c|c|c|c|c|c|c|c|}
\hline \multirow{3}{*}{$\begin{array}{l}\text { Nama } \\
\text { Bahan Makanan }\end{array}$} & \multicolumn{8}{|c|}{ Frekuensi Konsumsi Anak dalam Sebulan } & \multirow{3}{*}{$\begin{array}{c}\text { Nilai } \\
\mathrm{p}\end{array}$} \\
\hline & \multicolumn{4}{|c|}{ Perkotaan } & \multicolumn{4}{|c|}{ Perdesaan } & \\
\hline & $\begin{array}{l}\geq 90 \\
\text { kali }\end{array}$ & $\begin{array}{c}30-89 \\
\text { kali }\end{array}$ & $\begin{array}{l}<30 \\
\text { kali }\end{array}$ & $\begin{array}{l}\text { Tidak } \\
\text { pernah }\end{array}$ & $\begin{array}{l}\geq 90 \\
\text { kali }\end{array}$ & $\begin{array}{c}30-89 \\
\text { kali }\end{array}$ & $\begin{array}{l}<30 \\
\text { kali }\end{array}$ & $\begin{array}{c}\text { Tidak } \\
\text { pernah }\end{array}$ & \\
\hline Nasi/beras & 36,0 & 60,5 & 2,8 & 0,7 & 38,7 & 55,7 & 4,8 & 0,8 & 0,066 \\
\hline Mie/bihun & 0 & 1,8 & 86,4 & 11,7 & 0 & 2,4 & 87,0 & 10,6 & 0,779 \\
\hline Ubi jalar & 0 & 0 & 29,8 & 70,2 & 0 & 0,2 & 29,8 & 70 & 0,355 \\
\hline Singkong & 0,1 & 0 & 23,0 & 76,9 & 0 & 0,1 & 31,0 & 68,9 & 0,001 \\
\hline Daging unggas & 0,8 & 9,3 & 73,3 & 16,6 & 0,1 & 4,8 & 71,0 & 24,2 & 0,000 \\
\hline Daging sapi/sejenis & 0,1 & 4,7 & 67,4 & 27,8 & 0,1 & 1,7 & 65,0 & 33,3 & 0,001 \\
\hline Ikan laut & 0,5 & 4,7 & 51,1 & 43,7 & 0,7 & 9,8 & 56,7 & 32,8 & 0,000 \\
\hline Ikan tawar & 0 & 2,2 & 48,9 & 48,9 & 0,1 & 2,5 & 40,4 & 57,0 & 0,004 \\
\hline Telur ayam/bebek & 1,3 & 9,5 & 78,2 & 11,0 & 0,2 & 8,3 & 82,1 & 9,3 & 0,033 \\
\hline Tahu & 0,2 & 5,6 & 73,6 & 20,6 & 0,2 & 7,3 & 75,3 & 17,2 & 0,204 \\
\hline Tempe & 0,1 & 5,6 & 77,4 & 16,8 & 0,7 & 8,9 & 78,2 & 12,1 & 0,001 \\
\hline Jeruk & 0 & 1,0 & 54,5 & 44,4 & 0 & 0 & 54,5 & 45,5 & 0,012 \\
\hline Pepaya & 0 & 0,8 & 31,8 & 67,4 & 0 & 0,1 & 30,3 & 69,6 & 0,087 \\
\hline Pisang & 0 & 0,8 & 54,1 & 45,1 & 0,2 & 0,7 & 53,9 & 45,1 & 0,548 \\
\hline Bayam & 0 & 0,5 & 57,5 & 42,0 & 0 & 1,1 & 60,8 & 38,1 & 0,105 \\
\hline Kangkung & 0 & 0,3 & 34,9 & 64,7 & 0 & 0,5 & 44,9 & 54,6 & 0,000 \\
\hline Wortel & 0 & 0,9 & 63,5 & 35,6 & 0 & 0,5 & 44,8 & 54,8 & 0,000 \\
\hline Susu/produk susu & 27,0 & 36,1 & 26,9 & 9,9 & 11,4 & 29,9 & 37,5 & 21,2 & 0,000 \\
\hline Jajanan biskuit & 3,6 & 13,5 & 62,1 & 20,8 & 4,6 & 16,7 & 60,6 & 18,1 & 0,115 \\
\hline Jajanan chiki & 6,7 & 5,4 & 41,6 & 46,3 & 4,4 & 9,3 & 49,2 & 37,1 & 0,000 \\
\hline Jajanan permen & 2,5 & 6,1 & 55,4 & 36,0 & 5,2 & 7,3 & 60,4 & 27,1 & 0,000 \\
\hline Jajanan minuman & 3,3 & 9,0 & 38,1 & 49,6 & 2,7 & 6,1 & 36,4 & 54,8 & 0,050 \\
\hline
\end{tabular}


Ada perbedaan nyata pola konsumsi susu/produk susu, jajanan chiki, permen, dan jajanan minuman antara di perkotaan dan di perdesaan $(p<0,05)$. Pola konsumsi 22 jenis makanan pada kelompok umur 3-5 tahun disajikan pada Tabel 4.

Tabel 4 menunjukkan bahwa hampir semua anak pada kelompok umur 3-5 tahun mengonsumsi nasi/beras setiap hari, di perkotaan 99,3 persen dan 99,2 persen di perdesaan. Makanan sumber karbohidrat selain nasi/beras yang paling sering dikonsumsi adalah mie/bihun yang dikonsumsi minimal sekali dalam sebulan terakhir. Ubi dan singkong jarang dikonsumsi, meskipun dalam sebulan terakhir ada yang mengonsumsi setiap hari. Ada pebedaan nyata pola konsumsi nasi/beras dan singkong pada anak kelompok umur 3-5 tahun di perkotaan dan di perdesaan $(p<0,05)$.

Makanan sumber protein hewani yang paling sering dikonsumsi adalah daging unggas, daging sapi/kambing/babi, ikan laut, ikan tawar, dan telur, bahkan dalam sebulan terakhir ada yang mengonsumsi daging unggas, daging sapi/kambing/babi, ikan laut, dan telur sehari 3 kali. Telur dikonsumsi oleh 89 persen anak di perkotaan dan 90,7 persen di perdesaan. Ada perbedaan nyata pola konsumsi daging unggas, daging sapi/kambing/babi, ikan laut, ikan tawar, dan telur di perkotaan dan di perdesaan $(p<0,05)$. Daging unggas, daging sapi/kambing/ babi, dan ikan tawar lebih sering dikonsumsi oleh anak di perkotaan daripada di perdesaan, sedangkan ikan laut lebih sering dikonsumsi oleh anak-anak di perdesaan.

Frekuensi konsumsi tahu dan tempe anak 3-5 tahun dalam satu bulan terakhir termasuk tinggi, yaitu masing-masing di perdesaan 79,4 persen dan 83,2 persen, sedangkan di perkotaan 75,9 persen dan 79,4 persen. Ada perbedaan nyata pola konsumsi tempe di perkotaan dan di perdesaan $(p<0,05)$, sedangkan pola konsumsi tahu di perkotaan dan perdesaan tidak berbeda. Konsumsi buah pepaya dan pisang di perkotaan dan perdesaan tidak berbeda, namun konsumsi jeruk di perkotaan dan perdesaan berbeda nyata. Konsumsi bayam di perkotaan dan di perdesaan tidak berbeda, sedangkan konsumsi kangkung dan wortel berbeda nyata. Frekuensi konsumsi kangkung di perkotaan lebih rendah daripada di perdesaan, sebaliknya konsumsi wortel di perkotaan lebih tinggi daripada di perdesaan.

Pada anak umur 3-5 tahun frekeunsi konsumsi susu/produk susu dalam sebulan terakhir, khususnya di perkotaan sangat tinggi $(90,1 \%)$. Proporsi anak di perkotaan yang mengonsumsi susu/produk susu $\geq 1$ kali sehari sebanyak 63,1 persen bahkan 27 persen mengonsumsi susu/produk susu $\geq 3$ kali sehari. Di perdesaan 78,8 persen anak umur 3-5 tahun pernah mengonsumsi susu minimal sekali sebulan, bahkan 41,1 persen mengonsumsi minimal sekali sehari dan 11,4 persen mengonsumsi susu/produk susu $\geq 3$ kali sehari. Ada perbedaan nyata frekuensi konsumsi susu/produk susu di perkotaan dan di pedesaan. Frekuensi susu/produk susu di perkotaan lebin tinggi daripada di perdesaan.

Makanan jajanan biskuit, chiki, pemen dan jajanan minuman merupakan jenis jajanan yang paling sering dikonsumsi anak umur 3-5 tahun baik di perkotaan maupun di perdesaan. Ada perbedaan nyata konsumsi makanan jajanan chiki, permen dan jajanan minuman di perkotaan dan perdesaan. Frekuensi konsumsi jajanan chiki dan permen oleh anak di perdesaan lebih sering daripada di perkotaan, sedangkan frekuensi konsumsi jajanan minuman lebih sering pada anak di perkotaan. Frekuensi jajanan biskuit antara anak di perkotaan dan perdesaan tidak berbeda. Pola konsumsi makanan anak kelompok umur 6-8 tahun disajikan pada Tabel 5.

Umur 6-8 tahun adalah kelompok anak yang telah melewati masa balita. Anak sudah mulai dapat makan secara mandiri dan mengonsumsi jenis bahan makanan yang lebih bervariasi. Data tabel 5 menunjukkan bahwa konsumsi makanan sumber karbohidrat lebih bervariasi. Hal ini ditunjukkan dari proposi anak yang dalam sebulan terakhir mengonsumsi makan sumber karbohidrat selain nasi/beras, yaitu frekuensi konsumsi mie/bihun, ubi dan singkong. Proporsi anak yang pernah mengonsumsi mie/bihun dalam sebulan terakhir 93,1 persen di perkotaan dan 92,9 persen di perdesaan, bahkan 6,3 persen anak di perkotaan dan 3,7 persen di perdesaan mengonsumsi mie/bihun setiap hari. Ada perbedaan nyata frekuensi konsumsi mie/bihun dan singkong antara di perkotaan dan di perdesaan. Frekuensi konsumsi singkong lebih sering di perdesaan daripada di perkotaan. 
Tabel 5

Pola Konsumsi Makanan Anak Kelompok Umur 6-8 Tahun menurut Perkotaan dan Perdesaan

\begin{tabular}{|c|c|c|c|c|c|c|c|c|c|}
\hline \multirow{3}{*}{$\begin{array}{l}\text { Nama } \\
\text { Bahan Makanan }\end{array}$} & \multicolumn{8}{|c|}{ Frekuensi Konsumsi Anak dalam Sebulan } & \multirow{3}{*}{$\begin{array}{c}\text { Nilai } \\
p\end{array}$} \\
\hline & \multicolumn{4}{|c|}{ Perkotaan } & \multicolumn{4}{|c|}{ Perdesaan } & \\
\hline & $\begin{array}{l}\geq 90 \\
\text { kali }\end{array}$ & $\begin{array}{c}30-89 \\
\text { kali }\end{array}$ & $\begin{array}{l}<30 \\
\text { kali }\end{array}$ & $\begin{array}{c}\text { Tidak } \\
\text { pernah }\end{array}$ & $\begin{array}{l}\geq 90 \\
\text { kali }\end{array}$ & $\begin{array}{c}30-89 \\
\text { kali }\end{array}$ & $\begin{array}{l}<30 \\
\text { kali }\end{array}$ & $\begin{array}{l}\text { Tidak } \\
\text { pernah }\end{array}$ & \\
\hline Nasi/beras & 45,6 & 52,3 & 1,7 & 0,3 & 40,1 & 53,6 & 5,3 & 0,9 & 0,000 \\
\hline Mie/bihun & 0 & 6,3 & 86,8 & 6,9 & 0,5 & 3,2 & 89,1 & 7,1 & 0,001 \\
\hline Ubi jalar & 0 & 0,1 & 24,2 & 75,7 & 0 & 0,2 & 28,4 & 71,4 & 0,069 \\
\hline Singkong & 0,1 & 0,1 & 17,3 & 82,5 & 0 & 0,2 & 31,0 & 68,8 & 0,000 \\
\hline Daging unggas & 0,2 & 9,2 & 81,1 & 9,5 & 0,3 & 3,8 & 73,9 & 22,0 & 0,000 \\
\hline Daging sapi/sejenis & 0 & 4,4 & 68,7 & 26,9 & 0 & 2,3 & 60,9 & 36,8 & 0,000 \\
\hline Ikan laut & 0,8 & 4,1 & 51,2 & 43,8 & 2,1 & 11,5 & 55,3 & 31,0 & 0,000 \\
\hline Ikan tawar & 0 & 1,4 & 45,8 & 52,8 & 0 & 0,9 & 43,2 & 55,9 & 0,229 \\
\hline Telur ayam/bebek & 0 & 6,8 & 83,3 & 9,9 & 0,1 & 5,6 & 84,8 & 9,5 & 0,487 \\
\hline Tahu & 1,0 & 8,1 & 75,9 & 15,0 & 0,1 & 5,8 & 79,4 & 14,8 & 0,003 \\
\hline Tempe & 0,8 & 7,2 & 79,4 & 12,5 & 0,4 & 7,7 & 83,2 & 8,7 & 0,012 \\
\hline Jeruk & 0,4 & 1,4 & 57,7 & 40,6 & 0,4 & 0,5 & 50,6 & 48,5 & 0,001 \\
\hline Pepaya & 0 & 0,5 & 32,7 & 66,8 & 0 & 0,1 & 30,4 & 69,5 & 0,120 \\
\hline Pisang & 0,6 & 1,9 & 57,0 & 40,5 & 0 & 2,7 & 54,7 & 42,6 & 0,022 \\
\hline Bayam & 0 & 0,3 & 62,3 & 37,4 & 0,1 & 1,0 & 57,5 & 41,5 & 0,020 \\
\hline Kangkung & 0 & 0,6 & 45,8 & 53,6 & 0 & 0,8 & 45,7 & 53,5 & 0,906 \\
\hline Wortel & 0,3 & 0,2 & 60,6 & 38,9 & 0 & 0,4 & 43,6 & 56,0 & 0,000 \\
\hline Susu/produk susu & 8,6 & 35,0 & 39,2 & 17,1 & 2,4 & 20,9 & 43,3 & 33,4 & 0,000 \\
\hline Jajanan biskuit & 1,7 & 10,7 & 64,3 & 23,3 & 3,4 & 13,5 & 61,7 & 21,4 & 0,013 \\
\hline Jajanan chiki & 4,0 & 9,5 & 51,1 & 35,3 & 2,9 & 9,2 & 52,1 & 35,8 & 0,544 \\
\hline Jajanan permen & 1,9 & 4,4 & 51,9 & 41,8 & 4,0 & 5,8 & 57,5 & 32,7 & 0,000 \\
\hline Jajanan minuman & 5,2 & 10,2 & 40,2 & 44,4 & 3,0 & 11,3 & 38,6 & 47,1 & 0,038 \\
\hline
\end{tabular}

Pola konsumsi daging unggas, daging sapi/kambing/babi, dan ikan laut pada kelompok umur 6-8 tahun sama dengan pola konsumsi makanan tersebut pada kelompok umur 3-5 tahun. Ada perbedaan nyata frekuensi konsumsi daging unggas, daging sapi/kambing/ babi dan ikan laut anak di perkotaan dan di perdesaan. Frekuensi konsumsi daging unggas dan daging sapi/kambing/ babi lebih sering di perkotaan daripada di perdesaaan, sedangkan ikan laut lebih sering dikonsumsi oleh anakanak di perdesaan. Pola konsumsi ikan tawar dan telur tidak berbeda antara perkotaan dan di perdesaan. Frekuensi makanan sumber protein nabati yaitu tahu dan tempe termasuk tinggi, yaitu 85 persen dan 87,5 persen di perkotaan sedangkan di perdesaan 85,2 persen dan 92,3 persen. Pola konsumsi kedua makanan tersebut berbeda nyata antara di perkotaan dengan di perdesaan $(p<0,05)$. Frekuensi konsumsi tahu dan tempe pada anak 6-8 tahun lebih sering di perdesaan daripada di perkotaaan.
Frekuensi konsumsi buah jeruk dan pisang pada kelompok umur 6-8 tahun secara nyata lebih tinggi di perkotaan daripada di perdesaan $(p<0,05)$, sedangkan frekuensi konsumsi buah pepaya tidak ada perbedaan antara di perkotaan dan perdesaan. Pola konsumsi kangkung di perkotaan dan di perdesaan tidak berbeda, sedangkan pola konsumsi bayam dan wortel berbeda nyata $(p<0,05)$. Bayam dan wortel lebih sering dikonsumsi anak di perkotaan daripada anak di perdesaan.

Anak kelompok umur 6-8 tahun di perkotaan yang dalam sebulan terakhir pernah mengonsumsi susu/produk susu adalah 82,9 persen sedangkan di perdesaan 66,6 persen. Di perkotaan 43,6 persen anak pernah mengonsumsi susu/produk susu minimal 1 kali sehari, sedangkan di perdesaaan hanya 23,3 persen. Frekuensi konsumsi susu/produk susu antara anak di perkotaan dan di perdesaan berbeda nyata $(p<0,05)$. 
Tabel 6

Pola Konsumsi Makanan Anak Kelompok Umur 9-12 Tahun menurut Perkotaan dan Perdesaan

\begin{tabular}{|c|c|c|c|c|c|c|c|c|c|}
\hline \multirow{3}{*}{$\begin{array}{l}\text { Nama } \\
\text { Bahan Makanan }\end{array}$} & \multicolumn{8}{|c|}{ Frekuensi Konsumsi Anak dalam Sebulan } & \multirow{3}{*}{$\begin{array}{c}\text { Nilai } \\
p\end{array}$} \\
\hline & \multicolumn{4}{|c|}{ Perkotaan } & \multicolumn{4}{|c|}{ Perdesaan } & \\
\hline & $\begin{array}{l}\geq 90 \\
\text { kali }\end{array}$ & $\begin{array}{c}30-89 \\
\text { kali }\end{array}$ & $\begin{array}{l}<30 \\
\text { kali }\end{array}$ & $\begin{array}{l}\text { Tidak } \\
\text { pernah }\end{array}$ & $\begin{array}{l}\geq 90 \\
\text { kali }\end{array}$ & $\begin{array}{c}30-89 \\
\text { kali }\end{array}$ & $\begin{array}{l}<30 \\
\text { kali }\end{array}$ & $\begin{array}{c}\text { Tidak } \\
\text { pernah }\end{array}$ & \\
\hline Nasi/beras/bubur & 39,3 & 56,3 & 4,4 & 0 & 46,8 & 48,2 & 4,1 & 0,9 & 0,001 \\
\hline Mie/bihun & 0,4 & 2,0 & 93,0 & 4,6 & 0,1 & 5,8 & 84,0 & 10,1 & 0,000 \\
\hline Ubi jalar & 0 & 2,3 & 26,8 & 71,0 & 0 & 0,4 & 29,9 & 69,7 & 0,003 \\
\hline Singkong & 0 & 0 & 22,9 & 77,1 & 0 & 0,8 & 31,3 & 67,9 & 0,000 \\
\hline Daging unggas & 1,0 & 8,5 & 80,9 & 9,6 & 0 & 6,2 & 75,8 & 18,0 & 0,000 \\
\hline Daging sapi/sejenis & 0 & 3,4 & 78,4 & 18,3 & 0 & 1,9 & 64,0 & 34,0 & 0,000 \\
\hline Ikan laut & 0,6 & 10,1 & 57,3 & 32,0 & 1,8 & 13,0 & 53,5 & 31,6 & 0,038 \\
\hline Ikan tawar & 0 & 0,3 & 38,5 & 61,3 & 1,0 & 0,6 & 40,7 & 57,6 & 0,012 \\
\hline Telur ayam/bebek & 0,3 & 9,0 & 84,1 & 6,6 & 0,1 & 4,5 & 86,6 & 8,8 & 0,002 \\
\hline Tahu & 0 & 11,6 & 77,0 & 11,4 & 0,1 & 6,6 & 81,8 & 11,5 & 0,004 \\
\hline Tempe & 0,3 & 8,5 & 86,1 & 5,1 & 0 & 9,7 & 84,0 & 6,3 & 0,291 \\
\hline Jeruk & 0 & 1,4 & 60,8 & 37,9 & 0 & 0,4 & 53,1 & 46,5 & 0,000 \\
\hline Pepaya & 0 & 0 & 39,6 & 60,4 & 0 & 0,3 & 30,3 & 69,4 & 0,000 \\
\hline Pisang & 0 & 2,0 & 58,0 & 40 & 0,4 & 0,6 & 59,4 & 39,6 & 0,034 \\
\hline Bayam & 0 & 0,1 & 68,3 & 31,6 & 0 & 0,1 & 59,0 & 40,9 & 0,001 \\
\hline Kangkung & 0 & 0 & 59,9 & 40,1 & 0 & 0 & 53,9 & 46,1 & 0,051 \\
\hline Wortel & 0 & 0,1 & 60,6 & 39,3 & 0 & 0,5 & 45,3 & 54,2 & 0,000 \\
\hline Susu/produk susu & 2,9 & 28,7 & 42,9 & 25,5 & 1,0 & 20,6 & 45,9 & 32,5 & 0,000 \\
\hline Jajanan biskuit & 5,1 & 10,9 & 62,2 & 21,8 & 1,2 & 14,9 & 64,7 & 19,2 & 0,000 \\
\hline Jajanan chiki & 3,9 & 7,1 & 47,3 & 41,7 & 3,6 & 3,5 & 52,4 & 40,5 & 0,007 \\
\hline Jajanan permen & 1,0 & 2,8 & 50,9 & 45,4 & 3,2 & 3,1 & 54,8 & 38,9 & 0,002 \\
\hline Jajanan minuman & 4,4 & 7,8 & 47,4 & 40,5 & 1,7 & 8,6 & 41,9 & 47,8 & 0,001 \\
\hline
\end{tabular}

Frekuensi makanan jajanan biskuit, permen, dan minuman pada kelompok umur 6-8 tahun antara perkotaan dan perdesaan berbeda nyata $(p<0,05)$, sedangkan jajanan chiki tidak bebeda. Jajajan biskuit, permen, dan minuman lebih sering dikonsumsi anak di perdesaan dari di perkotaan. Frekuensi konsumsi makanan anak kelompok umur 9-12 tahun disajikan pada Tabel 6.

Tabel 6 adalah gambaran dari pola makan anak umur 9-12 tahun dimana pada umumnya anak sudah lebih mandiri dalam memilih makanan dan tidak tergantung bantuan orang tuanya. Pola konsumsi makan anak pada kelompok ini lebih bervariasi daripada kelompok yang lebih muda. Dari 22 kelompok atau jenis bahan makanan yang paling sering dikonsumsi anak umur 9-12 tahun, frekuensi konsumsi 20 jenis makanan antara anak di perkotaan dan perdesaan menunjukkan perbedaan nyata $(p<0,05)$, hanya dua jenis makanan yang tidak menunjukkan perbedaan antara frekuensi konsumsi di perkotaan dan perdesaan, yaitu tempe dan sayur kangkung.

Jenis makanan yang lebih sering dikonsumsi oleh anak di perdesaan adalah ubi, singkong, ikan laut, ikan tawar, buah pisang, jajanan biskuit, jajanan chiki, dan jajanan permen, sedangkan yang lebih sering dikonsumsi oleh anak di perkotaan adalah nasi/beras, mie/bihun, daging unggas, daging sapi/kambing/babi, telur ayam/bebek, tahu, buah jeruk, pepaya, sayur bayam, wortel, susu/produk susu, dan jajanan minuman. Jenis makanan yang paling sering dikonsumsi oleh lebih dari 90 persen anak di perkotaan dalam sebulan terakhir adalah nasi/beras, mie/bihun, daging unggas, telur ayam/bebek, dan tempe, sedangkan di perdesaan adalah nasi, telur ayam/bebek, dan tempe. Susu/produk susu adalah jenis makanan yang paling sering dikonsumsi minimal sekali sehari selain nasi/beras. 
Tabel 7

Pola Konsumsi Makanan Anak Kelompok Umur 6 Bulan - 12 Tahun menurut Perkotaan dan Perdesaan

\begin{tabular}{|c|c|c|c|c|c|c|c|c|c|}
\hline \multirow{3}{*}{$\begin{array}{l}\text { Nama } \\
\text { Bahan Makanan }\end{array}$} & \multicolumn{8}{|c|}{ Frekuensi Konsumsi Anak dalam Sebulan } & \multirow{3}{*}{$\begin{array}{c}\text { Nilai } \\
p\end{array}$} \\
\hline & \multicolumn{4}{|c|}{ Perkotaan } & \multicolumn{4}{|c|}{ Perdesaan } & \\
\hline & $\begin{array}{l}\geq 90 \\
\text { kali }\end{array}$ & $\begin{array}{c}30-89 \\
\text { kali }\end{array}$ & $\begin{array}{l}<30 \\
\text { kali }\end{array}$ & $\begin{array}{c}\text { Tidak } \\
\text { pernah }\end{array}$ & $\begin{array}{l}\geq 90 \\
\text { kali }\end{array}$ & $\begin{array}{c}30-89 \\
\text { kali }\end{array}$ & $\begin{array}{l}<30 \\
\text { kali }\end{array}$ & $\begin{array}{c}\text { Tidak } \\
\text { pernah }\end{array}$ & \\
\hline Nasi/beras/bubur & 36,6 & 56,3 & 4,2 & 2,9 & 36,7 & 54,6 & 5,5 & 3,2 & 0,054 \\
\hline Mie/bihun & 0,1 & 2,8 & 80,7 & 16,3 & 0,2 & 3,2 & 80,6 & 160 & 0,387 \\
\hline Ubi jalar & 0 & 0,6 & 25,2 & 74,2 & 0 & 0,3 & 26,6 & 73,1 & 0,082 \\
\hline Singkong & 0 & 0 & 20,1 & 79,8 & 0 & 0,2 & 28,4 & 71,3 & 0,000 \\
\hline Daging unggas & 0,5 & 8,1 & 74,2 & 17,2 & 0,1 & 4,2 & 69,0 & 26,7 & 0,000 \\
\hline Daging sapi/sejenis & 0 & 3,9 & 67,5 & 28,6 & 0,1 & 2,0 & 58,4 & 39,5 & 0,000 \\
\hline Ikan laut & 0,6 & 5,8 & 49,4 & 44,2 & 1,3 & 9,8 & 51,8 & 37,0 & 0,000 \\
\hline Ikan tawar & 0 & 1,1 & 43,3 & 55,6 & 0,2 & 1,5 & 39,7 & 58,6 & 0,000 \\
\hline Telur ayam/bebek & 0,4 & 7,5 & 78,5 & 13,5 & 0,2 & 5,8 & 79,9 & 14,2 & 0,003 \\
\hline Tahu & 0,4 & 7,4 & 73,8 & 18,5 & 0,2 & 5,9 & 75,3 & 18,6 & 0,031 \\
\hline Tempe & 0,3 & 6,6 & 77,6 & 15,5 & 0,3 & 7,7 & 78,2 & 13,8 & 0,080 \\
\hline Jeruk & 0,1 & 1,0 & 56,4 & 42,5 & 0,1 & 0,3 & 51,5 & 48,0 & 0,000 \\
\hline Pepaya & 0 & 0,4 & 35,3 & 64,3 & 0 & 0,1 & 28,2 & 71,6 & 0,000 \\
\hline Pisang & 0,2 & 1,6 & 55,8 & 42,4 & 0,2 & 1,4 & 53,4 & 45,1 & 0,115 \\
\hline Bayam & 0 & 0,6 & 62,3 & 37,1 & 0,1 & 1,3 & 58,7 & 39,9 & 0,001 \\
\hline Kangkung & 0 & 0,4 & 40,2 & 59,4 & 0 & 0,5 & 43,0 & 56,5 & 0,033 \\
\hline Wortel & 0,1 & 1,3 & 62,8 & 35,8 & 0 & 0,9 & 44,7 & 54,4 & 0,000 \\
\hline Susu/produk susu & 18,2 & 32,2 & 30,9 & 18,6 & 7,2 & 23,4 & 36,3 & 33,1 & 0,000 \\
\hline Jajanan biskuit & 3,3 & 11,8 & 62,6 & 22,2 & 3,3 & 14,3 & 61,7 & 20,7 & 0,014 \\
\hline Jajanan chiki & 3,8 & 6,6 & 43,5 & 46,1 & 3,4 & 6,5 & 46,7 & 43,4 & 0,047 \\
\hline Jajanan permen & 1,7 & 4,1 & 49,2 & 45,0 & 3,9 & 4,9 & 53,3 & 37,9 & 0,000 \\
\hline Jajanan minuman & 3,7 & 7,2 & 35,8 & 53,3 & 2,1 & 7,6 & 33,8 & 56,6 & 0,000 \\
\hline
\end{tabular}

Gambaran umum frekuensi konsumsi makanan pada semua kelompok umur ( 6 bulan12 tahun) disajikan pada Tabel 7 yang menunjukkan bahwa frekuensi konsumsi nasi/beras, mie/bihun/ubi, tempe, dan buah pisang pada anak umur 6 bulan - 12 tahun di perkotaan dan perdesaan tidak berbeda, sedangkan untuk 17 jenis makanan lainnya menunjukkan perbedaan nyata antara di perkotaan dan di perdesaan $(p<0,05)$.

Nasi/beras dan susu/produk susu merupakan jenis makanan yang paling sering dikonsumsi anak, baik di perdesaan maupun di perkotaan. Makanan jajanan juga termasuk makanan yang paling sering dikonsumsi selain nasi/beras dan susu/produk susu. Secara keseluruhan, pada anak umur 6 bulan - 12 tahun, jenis makanan yang ada perbedaan frekuensi dan variasi konsumsi makan antara di perdesaan dan di perkotaan meliputi 17 jenis makanan.

\section{BAHASAN}

Hasil penelitian Riskesdas 2013 memberikan gambaran bahwa proporsi konsumsi kurang sayur dan atau buah pada kelompok usia di atas 10 tahun masih rendah. ${ }^{3}$ Kualitas protein yang dikonsumsi berasal dari protein nabati seperti kacang-kacangan. Selain itu konsumsi makanan dan minuman berkadar gula tinggi, garam tinggi dan lemak tinggi baik pada masyarakat perkotaan maupun pedesaan. Gambaran hasil Riskesdas 2013 tentang konsumsi makanan berisiko pada penduduk berumur $\geq 10$ tahun menunjukkan bahwa konsumsi makanan dan minuman manis 53,1 persen dan makanan berlemak 40,7 persen. ${ }^{3}$

Berkaitan dengan hasil Riskesdas 2010, SEANUTS 2011 juga memberikan gambaran yang sama yaitu bahwa pola makan anak di Indonesia yang tinggal di perkotaan maupun di perdesaan adalah sama. Beberapa catatan dari hasil penelitian ini seperti frekuensi konsumsi 
yang rendah terutama pada sayur dan buahbuahan pada seluruh kelompok umur, konsumsi protein hewani, protein nabati juga kurang, hal ini dapat terlihat dari persentasi konsumsi harian yang masih rendah.

Tabel 2, 3, 4, 5, 6, dan 7 memperlihatkan variasi konsumsi 22 jenis bahan makanan. Frekuensi dan variasi makanan yang dikonsumsi pada kelompok umur yang lebih tua lebih baik daripada kelompok umur di bawahnya. Selain itu ada perbedaan frekuensi dan variasi konsumsi jenis makan antara di perdesaan dan perkotaan $(p<0,05)$. Pada kelompok umur 6-11 bulan hanya ada 4 jenis makan yang mempunyai perbedaan antara di perkotaan dan di perdesaan $(p<0,05)$. Pada kelompok umur 1-2 tahun, 3-5 tahun, 6-8 tahun, dan 9-12 tahun bertambah berturut-turut menjadi 13, 15, 16, dan 20 jenis makanan dengan frekuensi konsumsi berbeda antara di perkotaan dan perdesaan $(p<0,05)$.

Makanan pokok yang paling sering dikonsumsi adalah beras, terlihat pada semua kelompok umur, tidak ada bahan makanan lain yang dikonsumsi sebagai pengganti makanan pokok seperti mie, ubi, dan singkong. Memperhatikan anjuran Kementerian Kesehatan dalam Pesan Gizi Seimbang (PGS) 2014, variasi makanan anak di perkotaan maupun di perdesaan belum mencerminkan PGS dalam kehidupan sehari-hari. ${ }^{2}$

Frekuensi konsumsi makanan dan minuman jajanan dalam penelitian ini cukup tinggi, Hal ini menghawatirkan karena makanan jajanan, seperti: chiki dan permen, termasuk minuman kemasan gelas atau minuman serbuk tidak aman dan mengandung zat berbahaya. ${ }^{4,5}$ Kebiasaan makan makanan jajanan di perkotaan dan di perdesaan berbeda. Anakanak di perkotaan lebih sering mengonsumsi minuman gelas dan minuman serbuk, sedangkan di perdesaan lebih sering mengonsumsi chiki dan permen. Fakta di lapangan menunjukkan bahwa minuman kemasan gelas dan minuman serbuk dengan harga murah banyak yang menggunakan pemanis buatan dan pewarna minuman yang kurang layak dikonsumsi. Makanan jajanan rentan terhadap sanitasi yang kurang bersih dalam pembuatan dan penyimpanan, serta kontaminasi. ${ }^{6}$
Penelitian di Cameroon menemukan pada anak umur 12-59 bulan, mengonsumsi minyak, tepung terigu dan gula dengan frekuensi 1 kali sehari, selain itu juga mengonsumsi kaldu 2 kali dalam sehari. ${ }^{7}$ Mie/bihun yang sering dikonsumsi oleh anak-anak di Indonesia adalah mie instan. Frekuensi konsumsi mie lebih tinggi pada kelompok umur lebih tua dibandingkan kelompok umur lebih muda. Pada anak umur 611 bulan, 6,8 persen di perkotaan dan 8,8 persen di perdesaan sudah mulai diperkenalkan konsumsi mie dengan frekuensi minimal sekali dalam sebulan terakhir. Frekuensi konsumsi mie/bihun pada umur 1-2 tahun semakin sering, bahkan ada yang mengonsumsi 1-2 kali dalam sehari.

Hasil penelitian di Korea menunjukkan bahwa mengonsumsi mie instant 2 kali dalam seminggu meningkatkan risiko penyakit jantung metabolik 1,68 kali pada wanita. ${ }^{8} \mathrm{Hal}$ ini bukan berarti bahwa laki-laki bebas risiko tersebut, karena konsumsi makanan tinggi kalori dan tinggi garam juga merupakan faktor risiko penyakit degeneratif. Mie instant termasuk makanan dengan kadar kalori dan garam tinggi. ${ }^{6}$ Oleh karena penganekaragaman makanan khususnya nasi/beras dan mengganti dengan mie instant perlu dipertimbangkan dampaknya terhadap risiko penyakit jantung metabolik. Masyarakat perlu diberikan pendidikan atau penyuluhan tentang makan yang bervariasi dan risiko mengonsumsi mie instant yang sering terhadap penyakit metabolik, khususnya penyakit jantung.

Frekuensi konsumsi makan buah dan sayur pada anak umur 6 bulan - 12 tahun masih rendah. Proporsi anak yang mengonsumsi buah dan sayur setiap hari masih sangat rendah. Sebagian besar konsumsi sayur dan buah hanya dilakukan kurang dari sekali sehari atau tidak setiap hari. Di perkotaan, lebih dari 40 persen anak tidak pernah mengonsumsi buah dan lebih dari 35 persen sampel tidak pernah mengonsumsi sayuran dalam sebulan terakhir. Pola konsumsi buah dan sayur pada anak umur 6 bulan - 12 tahun belum memenuhi PGS. ${ }^{2} \mathrm{Hal}$ tersebut sama dengan hasil penelitian di Canada bahwa pada anak prasekolah dan sekolah dasar konsumsi buah dan sayur belum memenuhi rekomendasi. ${ }^{9,10}$ 


\section{SIMPULAN DAN SARAN}

\section{Simpulan}

Dari hasil studi ini dapat disimpulkan bahwa frekuensi dan jenis makanan yang dikonsumsi anak umur 6 bulan - 12 tahun berbeda, anak pada kelompok umur yang lebih tua frekuensi konsumsi makan makin tinggi. Secara keseluruhan dari 22 jenis makanan ada 17 jenis makanan dengan fekuensi konsumsi antara anak di perkotaan dan perdesaan berbeda. Jenis makanan yang lebih sering dikonsumsi anak di perkotaan adalah daging unggas, daging sapi/kambing/babi, ikan tawar, telur, tahu, jeruk, pepaya, bayam, wortel, susu/produk susu, dan jajanan minuman gelas atau serbuk. Jenis makanan yang lebih sering dikonsumsi oleh anak di perdesaan adalah singkong, ikan laut, kangkung, jajanan biskuit, jajanan chiki, dan jajanan permen. Untuk konsumsi sayur pada anak umur 6 bulan - 12 tahun, ternyata masih rendah baik di perkotaan maupun di pedesaan, karena masih sangat jarang anak yang mengonsumsi makanan tersebut setiap hari. Menariknya susu/produk susu adalah makanan selain nasi/beras yang paling sering dikonsumsi anak khususnya pada kelompok umur 1-12 tahun baik di perkotaan maupun di perdesaan. Konsumsi susu/produk susu sudah cukup banyak dikonsumsi setiap hari oleh anak di Indonesia khususnya di perkotaan. Untuk konsumsi makanan sumber protein hewani, daging unggas dan daging sapi/kambing/babi merupakan makan yang lebih sering dikonsumsi anak di perkotaan, sedangkan di perdesaan makanan sumber protein hewani yang sering dikonsumsi adalah ikan laut dan ikan tawar. Sumber protein lain seperti telur merupakan sumber protein hewani yang paling sering dikonsumsi anak di perkotaan dan perdesaan.

\section{Saran}

Risiko konsumsi mie instant yang terlalu sering dapat meningkatkan risiko penyakit jantung metabolik. Oleh karena itu perlu dilakukan pendidikan (penyuluhan) gizi dan kesehatan terkait dengan PGS. Pendidikan atau penyuluhan gizi dan kesehatan juga perlu terus dilakukan untuk meningkatkan frekuensi makan sayur dan buah pada anak-anak di Indonesia.

\section{UCAPAN TERIMA KASIH}

Penulis menyampaikan terima kasih kepada FrieslandCampina, dan Frisian Flag Indonesia.

\section{RUJUKAN}

1. Badan Litbang Kesehatan. Riset Kesehatan Dasar 2010. Laporan Nasional. Jakarta: Balitbangkes, 2010.

2. Direktorat Bina Gizi. Pedoman Gizi Seimbang. Jakarta: Direktorat Bina Gizi, 2014

3. Badan Litbang Kesehatan. Riset Kesehatan Dasar 2013. Laporan Nasional. Jakarta: Balitbangkes, 2013.

4. Cahyadi W. Analisis dan Aspek Kesehatan Bahan Tambahan Pangan. Edisi Kedua. Jakarta: Bumi Aksara. 2008.

5. Agustina F, Pambayun R, Febry F. Higiene dan Sanitasi pada Pedagang Makanan Jajanan Makanan Tradisional di Lingkungan SD di Kelurahan Kemang Lebar Daun, Palembang Tahun 2009. diunduh dari e.prints.unsri.ac.id/64/3/ Abstrak8.pdf. 2009.

6. Kaushik JS, Narang M, dan Parakh A. 2011. Fast Food Consumption in Children. Indian Pediatrics. 2011; 98 (48): 48-56.

7. Stone ER dan Ndjebayi NOA. Consumption of Potentially Fotifiable Foods by Women and Young Children Varies by Ecological Zone and Social Economic Status in Cameroon. The Journal of Nutrition. 2012; 142: 555-565.

8. Shin HJ, Cho E, Lee HJ, Fung TT, Rimm E, Rosner B, et al. Instant Noodle Intake and Dietary Patterns Are Associated with Distinct Cardiometabolic Risk Factors in Korea 1-4. The Journal of Nutrition. 2014; 144: 1247-1255.

9. Pabayo R, Spence JC, Casey L, and Storey K. Food Consumption Patterns In Preschool Children. Canadian Journal of Dietetic Practice and Research. 2012; 73 (2).

10. Moffat $T$ dan Galloway $T$. Food Consumption Patterns in Elementary School Children. Canadian Journal of Dietetic Practice and Research. 2008; 69 (3): 152-159. 